\title{
MODEL KOMUNIKASI PEMASARAN PAGUYUBAN BATIK TULIS
}

\author{
Fera Nurficahyanti \\ Program Studi Ilmu Komunikasi Fakultas Ilmu Sosial dan Ilmu Politik, Universitas \\ Pembangunan Nasional “Veteran" Yogyakarta, Jln Babarsari No. 2 Yogyakarta, \\ No Telp. (0274) 485268, \\ Email: ferranurcahyo@yahoo.com
}

\begin{abstract}
This study aims to find strategic model for marketing communications of Paguyuban Batik Tulis Giriloyo Bantul in increasing sales. Type of research is qualitative research. Data are collected by observation, document review and interview. The result shows that marketing communication strategy of Paguyuban Batik Tulis Giriloyo Bantul is still familial and simple. The biggest supporting factor in terms of marketing is Yogyakarta get new name predicate as the World Batik City so more people use batik. Inhibiting factor in the marketing communication strategy is lack of competence of marketing division.
\end{abstract}

Key Words: Batik, Marketing Communication Strategy.

\begin{abstract}
Abstrak
Penelitian ini bertujuan menemukan model strategi komunikasi pemasaran di Paguyuban Batik Tulis Giriloyo Bantul dalam meningkatkan penjualan. Jenis penelitian yang dilakukan adalah penelitian kualitatif. Data dikumpulkan melalui observasi, kajian dokumen dan wawancara. Hasil penelitian menunjukkan strategi komunikasi pemasaran Paguyuban Batik Tulis Giriloyo Bantul masih bersifat kekeluargaan dan sederhana. Faktor pendukung pemasaran ialah dinobatkannya Yogyakarta sebagai Kota Batik Dunia yang menjadikan makin banyak orang menggunakan kain batik. Faktor penghambat dalam strategi komunikasi pemasaran yaitu divisi pemasaran mengalami kesulitan Sumber Daya Manusia (SDM) yang kompeten.
\end{abstract}

Kata kunci: Batik, Strategi Komunikasi Pemasaran.

\section{Pendahuluan}

Indonesia terkenal akan kekayaan budayanya. Salah satu diantaranya adalah batik beraneka motif. Banyak daerah di Indonesia memiliki motif batik sendiri, namun batik paling identik dengan bangsa Indonesia adalah batik dari "Jawa". Batik merupakan kain bergambar yang melalui beberapa proses dan tahapan dalam pembuatannya.Batik pertama kali diperkenalkan kepada dunia oleh Presiden Soeharto saat menghadiri konferensi PBB. Padatanggal 2 Oktober 2009, UNESCO menetapkan batik sebagai Warisan Kemanusiaan untuk Budaya Lisan dan Nonbendawi (Masterpieces of the Oral and Intangible Heritage of Humanity) yang dinobatkan untuk Indonesia.

Seiring dengan perubahan zaman, batik semakin berkembang mulai dari motif, makna, corak, warna, proses pembuatan, hingga cara pemakaiannya.Kabupaten Bantul merupakan salah satu Kabupaten yang ada di Daerah Istimewa Yogyakarta. Seperti kota lainnya, Kabupaten Bantul memiliki perajin batik dibawah naungan Pemerintah Daerah Kabupaten Bantul. Salah satunya ialah perajin batik tulis di Giriloyo Bantul yang memiliki lebih dari enam ratus (600) perajin batik.

Pada tahun 2015, jumlah perajin batik di Kabupaten Bantul semakin bertambah. Penambahan jumlah perajin batik ini karena didukung dengan penetapan Yogyakarta sebagai Kota Batik Dunia. Penetapan Yogyakarta sebagai Kota Batik dunia diserahkan kepada GKR Pembayun pada peringatan 50 tahun Organisasi Dewan Kerajinan Dunia (WWC) di Dongyang, Tiongkok, pada 18-23 Oktober 
2014. Semakin banyak perajin batik baru yang muncul dengan adanya penobatan ini dan mengharuskan Paguyuban Batik Tulis Giriloyo Bantul mempunyai strategi untuk memasarkan produk.

Persaingan bisnis menuntut setiap kelompok perajin batik mencari strategi khusus. Di Kabupaten Bantul, sentra batik Giriloyo masuk ke dalam wilayah Desa Wukirsari Kecamatan Imogiri. Sentra ini memiliki sebuah paguyuban batik bernama Paguyuban Batik Tulis Giriloyo Bantul yang terdiri dari 13 kelompok kecil perajin batik dengan jumlah lebih dari enam ratus (600) perajin yang tersebar di enam pedusunan di wilayah Giriloyo Bantul. Dengan banyaknya jumlah perajin dalam bentuk organisasi kelompok, diperlukan sebuah pola hubungan baik dimana nantinya hubungan anggota-anggota dalam kelompok memiliki peran penting. Hubungan anggota-anggota dalam kelompok memiliki peranan penting dalam meningkatkan moral dan produktifitas mereka terlepas dari apakah kondisi kerja tersebut baik atau buruk (Mulyana. 2006: 60).

Munculnya kelompok perajin baru di Yogyakarta khususnya di Kabupaten Bantul membuat persaingan dalam dunia bisnis semakin ketat, para perajin juga dihadang dengan tugas mencari strategi yang tepat dalam memasarkan produknya. Setiap industri dituntut bersaing secara kompetitif dalam menciptakan dan memasarkan produk sesuai dengan keinginan konsumen.

Strategi pemasaran pada dasarnya merupakan pola langkah atau pola pikir yang harus dijalankan dan atau harus dijalankan di masa yang akan datang, setidaknya dalam kurun waktu tertentu. Pola pikir dan pola langkah tersebut harus diselaraskan searah dengan tujuan dan sasaran yang ingin dicapai (Nitisusastro, 2012: 13).

Fokus penelitian yang penulis lakukan adalah strategi komunikasi pema- saran. Dalam penelitian ini penulis melakukan penelitian di Paguyuban Batik Tulis Giriloyo Bantul. Batik Giriloyo terkenal memiliki batikan tangan warisan leluhur turun-temurun dengan motif keraton yang halus, dengan ciri khas warna soga (coklat). Beragam motif batik diproduksi disini setiap harinya.

Beberapa strategi harus terus dikembangkan oleh Paguyuban Batik Giriloyo Bantul agar bisa meningkatkan penjualan. Komunikasi yang baik antara pihak internal dan eksternal organisasi harus dibina dengan baikagarhubungan dengan pelanggan dapat berjalan. Hubungan dengan pelanggan merupakan poin penting dalam sebuah industri bisnis, hal tersebut dilakukan untuk meninggalkan kesan yang baik pada persepsi konsumen bahwa produsen mampu membangun komunikasi. Dalam membangun sebuah komunikasi dibutuhkan adanya strategi yang nantinya akan menjurus pada strategi berkomunikasi dalam hal pemasaran produk.

Dilihat dari sudut pandang produsen, konsumen individu atau konsumen institusi merupakan bagian penting dalam industri bisnis. Keduanya menyerap produk yang ditawarkan pelaku usaha di arena pasar. Tanpa konsumen tidak mungkin suatu usaha dapat berkembang (Nitisusastro, 2012: 27). Artinya, dalam sebuah hubungan membutuhkan lebih dari satu orang dan hubungan tersebut harus mampu dijaga dengan baik agar dapat berkelanjutan. Produsen yang menjalin komunikasi atau hubungan baik dengan konsumen memiliki potensi yang besar dalam memajukan usahanya.

Produsen harus menjaga hubungan baik dengan konsumen. Jika konsumen suka dengan produk dan produsen cerdas dalam menawarkan, konsumen akan setia dengan produk yang ditawarkan dan menciptakan profit tersendiri bagi produsen. Hubungan baik penting karena 
produsen dapat mengidentifikasi atau mengetahui kepuasaan konsumen terhadap barang yang ditawarkan. Dalam buku perilaku konsumen dalam perspektif kewirausahaan, dijelaskan bahwa dalam memahami apa, siapa, dan mengapa, konsumen, perlu dipelajari tentang berbagai perbedaan dan kesamaan relatif karakteristik yang melekat pada konsumen (Nitisusastro , 2012: 28). Komunikasi yang baik antara satu pihak dengan pihak lainnya akan mempermudah tercapainya tujuan. Keadaan demikianlah yang menunjukkan berhasilnya suatu proses komunikasi yang berlangsung antara kedua belah pihak termasuk dalam hubungan produsen dan konsumen. Adapun tujuan penelitian ini adalah menemukan model strategi komunikasi pemasaran bagi Paguyuban Batik Tulis Giriloyo Bantul dalam meningkatkan penjualan.

\section{Metode Penelitian}

Jenis penelitian yang dilakukan adalah penelitian kualitatif, yaitu metode penelitian yang berlandaskan pada filsafat postpositivisme, digunakan untuk meneliti pada kondisi obyek yang alamiah, (sebagai lawannya adalah eksperimen) dimana peneliti adalah sebagai instrumen kunci (Sugiyono, 2008: 9). Subjek penelitian ini para perajin batik yang terdaftar pada paguyuban batik tulis Giriloyo Kabupaten Bantul D.I.Yogyakarta. Metode pengumpulan data dengan wawancara mendalam mengenai strategi komunikasi pemasaran yang selama ini dilakukan serta faktor pendukung dan penghambat pelaksanaan strategi tersebut. Selain itu peneliti juga melakukan observasi dan dokumentasi atas perkembangan komunikasi pemasaran selama 6 bulan di Bantul.

\section{Hasil Penelitian dan Pembahasan}

\section{Strategi Komunikasi Pemasaran}

Paguyuban Batik Tulis Bantul dalam menjalankan strategi komunikasi pemasaran menggunakan teknik identifikasi pasar. Pasar dari batik tulis
Giriloyo adalah para wisatawan yang berkunjung ke Yogyakarta dankonsumen kelas menengah atas. Tetapi kurangnya pemahaman masyarakat terhadap seluk beluk dan kualitas batik dengan baik mengurangi kesadaran terhadap penghargaan batik tulis yang dibuat dengan proses yang lama, rumit, dan memiliki nilai-nilai filosofi yang luhur.

Strategi yang kedua yang diterapkan ialah dengan menelaah keunggulan produk yang dimiliki. Perajin dan pengurus Paguyuban memiliki kesadaran dan pemahaman yang dalam mengenai batik yang dihasilkan serta bagaimana cara memproduksinya. Batik tulis Giriloyo memiliki karakteristik unik yang menjadi keunggulan produk yang dihasilkan oleh masyarakat Giriliyo. Kelebihan produk batik tulis Giriloyoadalah hasil batikan yang benar-benar dikerjakan tanpa bantuan mesin atau alat. Motif yang dihasilkan hampir seluruhnya motif klasik Keraton Yogyakarta yang rumit. Perbedaan antara batik tulis dari Paguyuban Batik Tulis Giriloyo dengan batikan wilayah lain ialah dalam hal proses pewarnaan. Hampir semua proses pewarnaan menggunakan pewarna alami untuk mempertahankan kualitas produk hasil batikan. Selain menghasilkan produk batik, Paguyuban Batik Tulis Giriloyo Bantul menjual paket wisata pelatihan membatik yang diperuntukkan bagi masyarakat umum. Selain memiliki tujuan mendapatkan keuntungan, mereka memiliki misi memperkenalkan batik kepada masyarakat luas.

Dalam memasarkan produknya, Paguyuban Batik Tulis Giriloyo Bantul melakukan promosi penjualan yang dilakukan secara langsung atau dengan tatap muka. Kegiatan promosi penjualan yang dilakukan oleh Paguyuban Batik Tulis Giriloyo Bantul adalah mengikuti kegiatan-kegiatan yang diadakan oleh pemerintah baik itu pemerintah pusat maupun pemerintah daerah dengan cara 
mendaftarkan Paguyuban ke instansi pemerintah seperti Disperindakop, Dekranas, Bagian Kerjasama, serta Dinas Kebudayaan dan Pariwisata.

Berdasarkan hasil penelitian yang didapatkan untuk meningkat penjualan melalui strategi komunikasi yang dijalankan oleh Paguyuban Batik Tulis Giriloyo Bantul maka terdapat dua strategi yang bisa diterapkan yaitu : 1) Strategi Komunikasi ke Dalam (Internal). Membangun sebuah sistem komunikasi yang hangat antar anggota, komunikasi ini terjadi pada saat kegiatan-kegiatan yang sering dilakukan secara bersama. Contohnya pada rapat anggota Paguyuban Batik Tulis Giriloyo Bantul yang rutin setiap bulan dilakukan yakni setiap tanggal 15 (lima belas). Pada kegiatan ini setiap anggota bertukar pikiran dengan suasana kekeluargaan namun tetap serius. Seperti dalam visi Paguyuban Batik Tulis Giriloyo Bantul yakni terwujudnya rasa kekeluargaan dan kebersamaan dalam suatu lingkungan keluarga. Hal ini menjadikan atmosfer kekeluargaan untuk berkomunikasi bertukar pikiran terjaga. Melalui rapat rutin pengurus yang diikuti oleh dewan penasihat Paguyuban ini setiap anggota dapat bertukar pikiran mengenai harapan, keinginan, permasalahan, hingga tujuan yang ingin dicapai selanjutnya baik dalam ranah Paguyuban Batik Giriloyo Bantul atau jika ada permasalahan di setiap kelompok kecil. 2) Strategi Komunikasi Keluar (eksternal). Strategi ini memiliki kewajiban dimana Paguyuban Batik Tulis Giriloyo Bantulmerupakan wadah bagi seluruh perajin batik yang berjumlah lebih dari enam ratus (600) perajin batik untuk melakukan segala bentuk kegiatan berkaitan dengan hubungan kepada pemerintah, Lembaga Swadaya Masyarakat (LSM), Organisasi, Konsumen dan Perguruan Tinggi. Kegiatan-kegiatan ini beragam mulai dari mendaftarkan Paguyuban Batik
Tulis Giriloyo Bantul ke Disperindakop, KKPD, Dinas Kebudayaan dan Pariwisata Kabupaten Bantul, dan Dekranas.

\section{Faktor Pendukung dan Faktor Peng- hambat}

Pada kegiatan pemasaran, terdapat faktor pendukung dan faktor penghambat yang mempengaruhi efektivitas kegiatan komunikasi pemasaran Paguyuban Batik Tulis Giriloyo Bantul dalam upaya meningkatkan penjualannya. Dari observasi dan wawancara yang telah dilakukan peneliti maka hasil analisis adalah sebagai berikut:

\section{Faktor Pendukung}

Bulan April 2014 World Crafts Council (WCC) wilayah regional Asia Pasific, sebuah lembaga swasembada bertaraf intenasional yang berafiliasi dengan UNESCO menetapkan Yogyakarta sebagai Kota Batik Dunia. PenobatanYogyakarta sebagai Kota Batik Dunia memberikan dampak positif bagi Paguyuban Batik Tulis Giriloyo Bantul. Sebelum Yogyakarta mendapatkan gelar ini, sempat terjadi kelesuan dari masyarakat dalam membeli batik. Namun sekarang, banyak orang menjadi lebih cinta batik.

Dukungan lain datang dari Pemerintah Daerah Kabupaten Bantul melalui Dewan Kerajinan Kabupaten Bantul, Disperindakop, Badan Lingkungan Hidup Kabupaten Bantul, serta Dinas Kebudayaan dan Pariwisata dalam upaya mendukung kegiatan komunikasi pemasaran Paguyuban Batik Giriloyo Bantul. Hal ini ditunjukkan dengan pemberian bantuan berupa alat dan pelatihan.

Dengan terdaftarnya Paguyuban Batik Tulis Giriloyo Bantul sebagai usaha yang diakui keberadaannyamenjadikan peluang bagi Paguyuban Batik Tulis Giriloyo Bantul dalam kegiatan pemasaran karena diikut sertakan mengikuti pameran seperti InaCraft, TextCraft, Jogja Fashion Weeksecara gratis. 
Kebijakan baru dibuat pemerintah dalam mendukung penobatan Yogyakarta sebagai Kota Batik Dunia dan kegiatan produksi perajin batik yaitu pegawai pemerintah wajib menggunakan seragam batik pada hari tertentu setiap minggunya. Selain itu pegawai non pemerintah, hingga anak sekolah wajib memiliki batik dan memakainya pada hari tertentu. Kebijakan ini sesuai dengan Peraturan Bupati Kabupaten Bantul Nomor 32 Tahun 2014 tentang Pakaian Dinas Aparatur Pemerintah di Lingkungan Pemerintah Kabupaten Bantul sejalan dengan Peraturan Gubernur Daerah Istimewa Yogyakarta Nomor 72 Tahun 2008 tentang Budaya Pemerintahan di Daerah Istimewa Yogyakarta, yang selanjutnya diatur dalam pasal 12 ayat 1,2,3,4 yang berbunyi aparatur pemerintah wajib memakai pakaian batik di hari Kamis dan Jumat, serta dilengkapi dengan atribut kartu tanda pengenal sesuai peraturan perundang-undangan (www.perbupbantulkab.com, diakses 8 Februari 2015 Pukul 12.25)

Dukungan pemerintah juga datang melalui kebijakan yang dikeluarkan tentang pelarangan produksibatik dengan sistem printing sangat mendukung pelaku usaha dalam bidang ini terutama bagi perajin di Paguyuban Batik Tulis Giriloyo Bantul. Dengan adanya pelarangan produksi batik printing di Bantul, menjadikan persaingan diantara para perajin tidak terlalu terpaut jauh saat menentukan harga.

\section{Faktor Penghambat}

Dari hasil wawancara dengan beberapa informan baik itu perajin, konsumen, dan pengurus Paguyuban Batik TulisGiriloyoBantul, semuamengeluhkan adanya hambatan berupa kesulitan mendapatkan sinyal baik itu sinyal dari provider untuk menggunakan sosial media seperti Whatsapp atau BlackBerry Messanger. Jaringan internetsulit masuk ke wilayah ini. Diperlukan daerah yang lebih tinggi atau keluar dari sentra batik Giriloyo jika ingin mengunggah foto batik bagi pengurus Paguyuban Batik Tulis Giriloyo Bantul divisi pemasaran. Tidak hanya itu, letak geografis yang kurang strategis juga menjadi faktor penghambat kegiatan pemasaran.

Belum adanya fasilitas mesin ATM dan mesin gesek diakui oleh perajin dan pengurus Paguyuban Batik Tulis Giriloyo Bantul yang menjadikan salah satu kendala besar di bidang pemasaran. Banyak pengunjung yang datang tidak membawa uang tunai. Sedangkan keberadaan mesin atm sangat jauh. Pengunjung harus keluar dari sentra batik tulis Giriloyo Bantul dan menempuh jarak sekitar 3 kilometer untuk bisa mengambil uang di mesin ATM. Mesin ATM pun tidak lengkap.Dikarenakan hal ini, banyak pengunjung yang membatalkan transaksi.

Kendala lain yang dihadapi ialah perajin di Paguyuban Batik Tulis Giriloyo Bantul didominasi usia lanjut. Sedikitnya jumlah perajin dengan prosentase 1020\% yang berusia 20-30 tahun dari total jumlah pembatik di Paguyuban Batik Tulis Giriloyo Bantul menjadi suatu masalah yang harus dipecahkan sesegera mungkin. Jika tidak ketakutan akan berkurangnya generasi penerus perajin batik akan menjadi kenyataan. Selain itu karena didominasi usia lanjut, dari sekian jumlah pengurus Paguyuban Batik Tulis ini, mereka belum bisa memanfaatkan promosi menggunakan media sosial. Walaupun telah ada divisi pemasaran, namun hanya satu (1) orang yang bisa mengoperasionalkan website dan masih seadanya.

Faktor usia dan kurangnya manajemen profesional yang dipakai, informan dari segi konsumen terkadang mengeluhkan waktu yang diperlukan untuk menunggu hasil kain batikan yang 
dipesan karena terkadang memerlukann waktu yang lama untuk memprosesnya. Hal ini diakui oleh perajin. Jika memiliki banyak pesanan, data pemesan yang lebih awal memesan kain batik kurang terkontrol datanya. Sehingga tidak jarang dibutuhkan waktu 1 bulan lebih untuk menanti hasilnya. Tidak jarang perajin yang didominasi usia lanjut sering lupa membuatnya jika sudah dikejar orderan membuat batik yang lain.

\section{Taktik dan Implementasi}

Taktik dan implementasi strategi pemasaran Paguyuban Batik Tulis Giriloyo Bantul dilakukan dengan menggunakan konsep marketing mix yaitu Four $P^{\prime}$ 'S atau biasa disebut $4 \mathrm{P}$ sebagai berikut : (1) Product (Produk). Dalam konsep marketing mix, faktor paling utama yang harus terlebih dahulu diketahui adalah tentang produk yang ditawarkan. Dengan mengetahui suatu produk, maka akan diketahui apakah produk tersebut sesuai dengan apa yang dibutuhkan atau tidak. Produk yang ditawarkan Paguyuban Batik Tulis Giriloyo Bantul sebelumnya sudah direncanakan dan ditetapkan segmen pasarnya. Produk batik sebagai andalan produk barang yang ditawarkan ke konsumen, ada juga fasilitas gazebo yang di dalamnya terdapat joglo dan showroombatik. Selain itu Paguyuban Batik Tulis Giroloyo Bantul juga menjual paket "Belajar Membatik"; (2) Price (Harga). Harga adalah salah satu unsur yang terdapat dalam konsep promotion mix yang digunakan oleh perusahaan atau organisasi untuk mencapai tujuan pemasarannya. Dalam hal ini, produk terlebih dahulu dilihat bagaimana harga tersebut bisa sesuai untuk menjualnya, dan tidak jarang pula dijadikan sebagai alat penyeimbang.Di Paguyuban Batik Tulis Giriloyo Bantul, harga sebuah barang memiliki pesan tentang makna batik, bagaimana proses pembuatan batik tersebut, cerita, berapa lama proses pembuatannya, tingkat kerumitannya, hingga berbicara tentang seberapa halus hasil batikan. Harga batik di Paguyuban Batik Tulis Giriloyo Bantul beragam yang dibandrol mulai dari Rp 450.000,- (empat ratus lima puluh ribu rupiah) hingga Rp 1.500.000,- (Satu Juta Lima Ratus Ribu Rupiah). Namun ada juga kain batik mencapai harga $\mathrm{Rp}$ 5.000.000,- (Lima Juta Rupiah) hingga di bandrol dengan harga Rp 10.000.000,(Sepuluh Juta Rupiah). Penentuan harga disesuaikan dengan segmentasi pasar yang dituju Paguyuban Batik Tulis Giriloyo Bantul. Untuk harga kain batik segmentasi pasar ialah untuk golongan menengah keatas. Sedangkan untuk paket "belajar membatik" dijual dengan harga Rp 25.000,- (Dua Puluh Lima Ribu Rupiah), $\quad$ Rp 35.000,- (Tiga Puluh Lima Ribu Rupiah), dan Rp 50.000,- (Lima Puluh Ribu Rupiah); (3) Place (Lokasi). Fungsi utama dari kegiatan distribusi adalah menyalurkan barang atau jasa dalam hal ini ialah informasi produk yang dipasarkan Paguyuban Batik Tulis Giriloyo Bantul ke konsumen dengan menentukan saluran kegiatan distribusi yang tepat dan sesuai sehingga dapat diterima baik oleh mereka. Paguyuban Batik Tulis Giriloyo Bantul telah memiliki Gazebo sebagai showroom untuk menjual batiknya yang terletak di Desa Wukirsari, Kecamatan Imogiri.Lokasi yang tergolong jauh menyebabkan kurangnya minat masyarakat untuk datang berkunjung khususnya warga Yogyakarta sendiri. Hal ini merupakan permasalahan yang harus dipecahkan dalam hal distribusi produk. Banyak yang bisa dilakukan seperti menempatkan produknya dengan mendistribusikan ke toko-toko besar di Yogyakarta untuk meningkatkan penjualan, atau dengan membuat sentra batik tulis Giriloyo Bantul menjadi tempat yang lebih menarik sehingga akan 
banyak konsumen yang akan berkunjung; (4) Promotions (Promosi). Paguyuban Batik Tulis Giriloyo Bantul dalam memperkenalkan produknya menggunakan konsep 3 (tiga) strategi promotion mixyang meliputi iklan, promosi penjualan, dan pemasaran langsung. Ketiganya yaitu : (a) Advertising (Periklanan). Dalam kegiatan strategi komunikasi pemasaran Paguyuban Batik Tulis Giriloyo Bantul menggunakan beberapa media iklan seperti brosur dan kartu nama. Sejauh ini Paguyuban Batik Tulis Giriloyo Bantul tidak menggunakan iklan di media cetak, televisi, radio, serta papan reklame atau baliho yang di sengaja untuk kegiatan promosi dikarenakan biaya sangat mahal dan kurang terjangkau; (b) Sales Promotion (Promosi Penjualan). Promosi penjualan adalah promosi yang dilakukan secara langsung. Kegiatan promosi penjualan yang dilakukan oleh Paguyuban Batik Tulis Giriloyo Bantul adalah mengikuti kegiatan-kegiatan yang didukung oleh pemerintah baik itu pemerintah pusat maupun pemerintah daerah. Paguyuban Batik Tulis Giriloyo Bantul memanfaatkan peluang yang diberikan oleh pemerintah dalam kegiatan strategi komunikasi pemasaran menggunakan metode promosi penjualan tatap muka (mengikuti pameran, menyebar brosur, dan kartu nama); (c)Direct Marketing (Pemasaran Langsung). Paguyuban Batik Tulis Giriloyo Bantul melakukan strategi pemasaran langsung dengan adanya gazebo.Kegiatanyang dilakukandilakukan searah dengan konsep bauran pemasaran langsung ialah penjualan tatap muka dimana Paguyuban Batik Tulis Giriloyo Bantul memiliki showroom bersama yang disebut gazebo, kios-kios kecil yang mendisplay kain batik jualannya di setiap kelompok kecil, serta promosi melalui saluran online yaitu website. Hanya saja dalam hal pemasaran langsung melalui media online belum optimal dikarenakan beberapa kendala seperti sulitnya sinyal dan minimnya sumberdaya manusia yang bisa mengoperasionalkan komputer apalagi mengelola media sosial.

Menurut pengamatan dan penelitian yang penulis lakukan di Paguyuban Batik Tulis Giriloyo Bantul, hasil penelitian didapat memperkuat teori perencanaan yang menjelaskan bahwa dalam kegiatan perencanaan diperlukan rencana yang disusun secara terkonsep untuk mencapai sebuah tujuan.Peneliti memperoleh data bahwa mereka sudah melakukan upayaupaya yang sudah sesuai dengan teori perencanaan dan konsep marketing mix. Walaupun belum sesuai seratus persen. Upaya-upaya yang mereka lakukan ialah mengadakan rapat rutin setiap bulannya. Namun ditemukan masih ada beberapa kelemahan yaitu hasil rapat tidak ternotulen dengan baik, hasil putusan rapat tidak segera ditindak lanjuti.

Paguyuban Batik Tulis Giriloyo sebagaimana visinya adalah kekeluargaan, oleh karena itu dalam promosinya semua anggota dan pengurus dalam Paguyuban ikut serta membantu menjalankan kegiatan komunikasi pemasaran untuk mempromosikan produk. Dalam praktiknya, memang ada yang bertanggungjawab penuh untuk merumuskan dan memasarkan produk batik tulis yang dibuat anggota paguyuban yaitu divisi pemasaran yang memiliki anggota sebanyak 3 (tiga) orang. Namun semua memiliki kewajiban menjalankan komunikasi pemasaran ini bersama-sama. Jika ada pengunjung atau tamu yang datang ke sentra batik Giriloyo,semua wajib menyambut dengan ramah. Dengan keramahan ini pengurus Paguyuban Batik Tulis Giriloyo Bantul mengharapkan adanya keunikan minat serta kunjungan dari konsumen atau pengunjung untuk datang lagi ke sentra batik Giriloyo.

Dalam hal produksi mereka sudah mempunyai produk yang siap 
dipasarkan berupa batik tulis dan jasa "belajar membatik" walaupun harga yang ditawarkan relatif mahal. Paguyuban telah memiliki sentra promosi berupa showroom yang menampung hasil batik, tetapi dari segi akses jalan menuju kesana jauh dari pusat kota, sehingga memerlukan waktu yang cukup lama untuk sampai ke sentra ini. Walaupun jalan sudah diaspal, jalan menuju ke sentra ini masih sempit dan belum ada petunjuk arah. Konsumen harus turun dan bertanya di jalan apabila belum pernah datang ke sentra ini. Kegiatan promosi sudah dilakukan, namun yang dilakukan baru sampai pada tataran brosur, kartunama, dan website yang sudah ada namun belum dimanfaatkan secara optimal karena keterbatasan pengetahuan dan sulitnya sinyal.

Hasil pengumpulan data yang telah dilakukan oleh peneliti dengan menggunakan teknik wawancara dan observasi lapangan menunjukkan bahwa strategi komunikasi pemasaran yang dipakai masih bersifat tradiosional, lebih menggunakan strategi komunikasi pemasaran dari mulut ke mulut. Dari pengumpulan data di lapangan tersebut ditemukan model komunikasi pemasaran yang dirasa dapat diaplikasikan guna menunjang kegiatan pemasaran yang digambarkan dalam bagan.1.

Persoalan dalam bagan 1 dideskripsikan dari hasil FGD sebagai berikut; Model komunikasi yang ditemukan memadukan unsur-unsur komunikasi pemasaran terpadu. Dalam model tersebut dijelaskan dalam mencapai sebuah tujuan, diperlukan perencanaan sesuai dengan teori dari Charles Berger dimana rencana-rencana dari perilaku komunikasi adalah "representasi kognitif hierarki dari rangkaian tindakan mencapai tujuan". Dengan kata lain rencana-rencana merupakan gambaran dari langkah-langkah yang akan diambil seseorang dalam memenuhi sebuah tujuan. Perencanaan

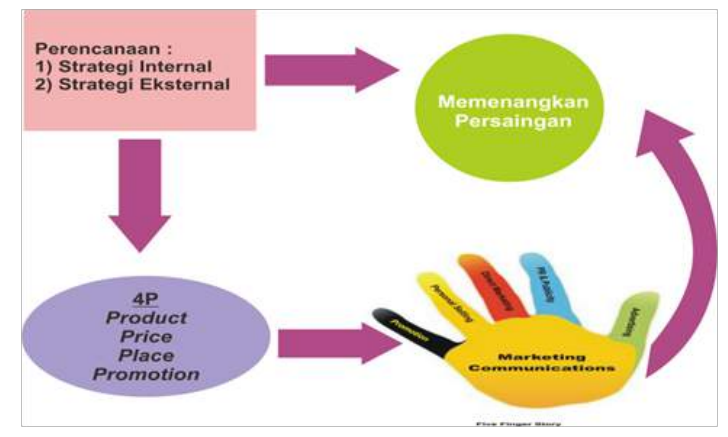

Bagan 1. Model Komunikasi Pemasaran

adalah proses rencana-rencana tindakan. Perencanaan pesan merupakan perhatian utama karena komunikasi sangat penting dalam meraih tujuan. Semuanya disebut hierarki karena tindakan-tindakan tertentu diperlukan untuk menyusun segala sesuatunya, sehingga tindakan-tindakan lain dapat diambil. Perencanaan pesan merupakan perhatian utama karena komunikasi sangat penting dalam meraih tujuan (Littlejohn. 2011: 184-185).

Proses perencanaan Paguyuban Batik Tulis Giriloyo Bantul ditemukan telah menggunakan 2 (dua) strategi yaitu strategi ke dalam dan strategi keluar. Ditemukan pula dalam menjalankan strategi masih menggunakan konsep Four $P^{\prime} S$ atau 4P dimana di dalamnya diaplikasikan dalam konsep marketing mix yaitu product (produk), price (harga), place (distribusi atau tempat), dan promotions (promosi). Kegiatan promosi dilakukan melalui iklan, pemasaran langsung, dan promosi penjualan. Ketiga bauran komunikasi pemasaran yang digunakan tersebut memiliki kegiatan yang berbeda. Namun dalam penelitian ini, ditemukan pengembangan ide strategi komunikasi pemasaran guna menarik minat pasar, yaitu dalam kegiatan strategi komunikasi pemasaran didukung dengan kegiatan promotions mix yaitu Sales Promotion, Personal Selling, Direct Marketing, Advertising, dan kegiatan Public Relations.

Bagan tersebut menjelaskan tentang strategi komunikasi pemasaran yang sebaiknya diterapkan oleh Paguyuban Batik 
Tulis Giriloyo Bantul dimana jika model ini diaplikasikan akan lebih menunjang kegiatan pemasaran. Berkaitan dengan hal ini pengurus Paguyuban Batik Tulis Giriloyo Bantul terutama divisi pemasaran dituntut untuk dapat menggunakan aplikasi media sosial seperti website, facebook, twitter, hingga instagram. Fakta dilapangan menunjukkan bahwa divisi pemasaran Paguyuban Batik Tulis Giriloyo Bantul belum memiliki kompetensi menggunakan media sosial tersebut. Hasil penelitian ini merekomendasikan agar divisi pemasaran Paguyuban Batik Tulis Giriloyo Bantul melibatkan anak muda di Giriloyo agarke 5 (lima) strategi ini dapat dijalankan secara dan menunjang jumlah produksi.

Dalam menggunakan media periklanan yang ada yaitu brosur dan kartu nama masih ditemukan masih memiliki desain seadanya. Desain yang digunakan masih sangat minimalis. Desain kartunama akan lebih baik jika diperbaiki dengan desain yang baru. Brosur yang telah ada masih bergabung dengan desa wisata Wukirsari. Sebaiknya untuk menunjang kegiatan promosi mulai dibuat brosur dan flyer baru yang berfokus pada produk yang ditawarkan Paguyuban Batik Tulis Giriloyo Bantul. Kepada pihak-pihak yang terkait diharapkan memberikan kontribusi untuk meningkatkan termasuk dari pemerintah daerah dan seluruh pengurus di Paguyuban Batik Tulis Giriloyo Bantul agar Paguyuban ini dapat mencapai tujuan yang diinginkan yaitu mencapai tujuan memenangkan persaingan pasar.

\section{Simpulan}

Berdasarkan hasil penelitian yang telah dilakukan, maka dapat diambil kesimpulan dan saran sebagai berikut; 1) Paguyuban Batik Tulis Giriloyo Bantul merupakan bidang usaha seni kerajinan batik yang didalamnya menaungi 13 kelompok perajin batik tulis dengan jumlah anggota lebih dari enam ratus (600) perajin. Didirikannya Paguyuban
Batik Tulis Giriloyo Bantul memiliki tujuan sebagai wadah bagi para pembatik kelompok kecil agar bisa mengoptimalkan penjualan batik serta mencegah adanya perselisihan yang mungkin bisa terjadi di antara kelompok perajin batik di Giriloyo Bantul. 2) Paguyuban Batik Tulis Giriloyo Bantul telah menggunakan konsep strategi pemasaran. Strategi komunikasi pemasaran yang dilakukan mempunyai tujuan agar Paguyuban Batik Tulis Giriloyo Bantul bisa ikut berkembang dan bersaing dengan kompetitor dalam hal penjualan produk dan memenangkan persaingan pasar. 3) Strategi komunikasi pemasaran yang dilakukan oleh Paguyuban Batik Tulis Giriloyo Bantul menggunakan konsep marketing mix yang dijabarkan dalam product (produk), price (harga), place (distribusi atau tempat), dan promotions (promosi) dalam kegiatannya yang juga ditunjang dengan kegiatan promosi melalui iklan, pemasaran langsung, dan promosi penjualan. 4) Sebaiknya dalam kepengurusan Paguyuban Batik Tulis Giriloyo Bantul dilibatkan anak muda di Giriloyo khususnya bagian pemasaran agar dapat memaksimalkan strategi dari model komunikasi pemasaran untuk menunjang jumlah produksi.

Para perajin batik akan sukses dalam pemasaran apabila selalu memperbarui strategi komunikasi pemasaran sesuai perkembangan teknologi komunikasi. Hal ini terjadi karena calon konsumen dan konsumen batik banyak menggunakan teknologi komunikasi terbaru dalam belanja batik.

\section{Daftar Pustaka}

Littlejohn, W, Stephen \& Foss A, Karen. 2011. Teori Komunikasi (Theories of Human Communications). Jakarta : Salemba Humanika.

Mulyana, Deddy. 2006. Komunikasi Organisasi : Strategi Meningkatkan Kinerja Usaha. Bandung : Remaja Rosdakarya. 
Nitisusastro, Mulyadi. 2012. Perilaku Konsumen dalam Perspektif Kewirausahaan. Bandung : Alfabeta.

Mulyana, Deddy. 2006. Komunikasi Organisasi : Strategi Meningkatkan Kinerja Usaha. Bandung : Remaja Rosdakarya.
Nitisusastro, Mulyadi. 2012. Perilaku Konsumen dalam Perspektif Kewirausahaan. Bandung: Alfabeta.

Sugiyono. 2008. Metode Penelitian Kuantitatif Kualitatifdan RED. Bandung: Alfabeta.

\section{Internet}

www.perbupbantulkab.com, diakses 8 Februari 2015 Pukul 12.25 